\title{
Adipocytokines and their relationship to endometrial cancer risk: a systematic review and meta-analysis.
}

ELLIS, P.E., BARRON, G.A. and BERMANO, G. 
1 Adipocytokines and their relationship to endometrial cancer risk: a systematic review

2 and meta-analysis

3 Patricia E Ellis ${ }^{1,2}$, Gemma A. Barron ${ }^{1}$, Giovanna Bermano ${ }^{1}$

$4{ }^{1}$ Centre for Obesity Research and Education (CORE), School of Pharmacy and Life Sciences,

5 Robert Gordon University, Garthdee Road, Aberdeen, AB107GJ

$6 \quad{ }^{2}$ Royal Surrey County Hospital, Egerton Road, Guildford, Surrey GU2 7XX

7 Corresponding author:

8 Dr Giovanna Bermano

9 Centre for Obesity Research and Education (CORE)

10 School of Pharmacy and Life Sciences

11 Robert Gordon University

12 Sir Ian Wood Building

13 Garthdee Road

14 Aberdeen AB10 7GJ

15 Telephone number: 01224262885

16 E-mail address: g.bermano@rgu.ac.uk

17

18 Keywords: Endometrial cancer, Obesity, Adipocytokines, Risk factors, Meta-analysis 


\section{HIGHLIGHTS}

21 - Participants with reduced adiponectin levels are more likely to develop endometrial cancer

22 regardless of their BMI status, history of hypertension or diabetes.

23 - When considering participants with high BMI or a history of diabetes, increased leptin

24 levels confer a greater risk of endometrial cancer

25 - Larger studies are required to establish the role of TNF- $\alpha$ and IL-6 in the development of 26 endometrial cancer

27 
ABSTRACT

\section{Objective}

30 To investigate the association between circulating levels of adipocytokines (adiponectin, leptin, 31 tumour necrosis factor alpha (TNF $\alpha$ ), interleukin 6 (IL-6)) and growth factors (insulin-like 32 growth factor I (IGF-I) and II (IGF-II)), and the risk of endometrial cancer.

\section{Methods}

34 Cochrane, CINAHL, Embase, Medline and Web of Science were searched for English35 language manuscripts published between January 2000 and August 2018 using the following 36 string of words: cancer and endometrial and (obesity or BMI) and (adiponectin or TNF* or 37 IGF-I or IGF-II or IL-6 or leptin).

\section{Results}

39 Twenty articles were included in this meta-analysis, which corresponded to 18 studies involving 402921 endometrial carcinoma cases and 5302 controls. Fourteen articles reported circulating 41 levels for adiponectin, seven for leptin, three for TNF $\alpha$, three for IL-6 and one for IGF- I. No 42 article reported values for IGF- II.

43 Patients with circulating adiponectin levels in the highest tertile had decreased endometrial cancer risk compared to women with levels in the lowest tertile, (summary of odds ratio (SOR) $0.51,95 \%$ CI: $0.38-0.69, \mathrm{p}<0.00001)$. Women with circulating leptin concentrations in the highest tertile had increased endometrial cancer risk compared to women with concentrations

47 in the lowest tertile (SOR 2.19, 95\% CI: 1.45-3.30, $\mathrm{p}=0.0002$ ). There was no difference in 48 cancer risk between participants with the highest TNF $\alpha$ and IL-6 levels compared to the lowest 49 levels (SOR 1.27, 95\% CI: 0.88-1.83, $\mathrm{p}=0.20$ and SOR 1.20, 95\% CI: $0.89-1.63, \mathrm{p}=0.23$, 50 respectively).

\section{Conclusions}


52 Endometrial cancer risk is inversely affected by adiponectin and leptin levels. There appears to 53 be no relationship between TNF- $\alpha$ and IL- 6 and the overall risk of endometrial cancer. 


\section{Background}

55 The exact biological mechanism underlying the development of endometrial cancer is still

56 poorly understood. In the UK, endometrial cancer is the $4^{\text {th }}$ most common female cancer;

57 approximately 9000 women were diagnosed with endometrial cancer in 2015 [1]. Worldwide,

58320000 new cases of endometrial cancer were diagnosed in 2012 [2].

59 Obesity is a well-recognised risk factor for endometrial cancer; however, the relationship between obesity and endometrial cancer is complex and likely to involve multiple biological

61 pathways. Sex steroid and insulin pathways, chronic inflammation and alterations in circulating

62 levels of adipokines have all been suggested as potential mechanisms affecting endometrial 63 cancer risk [3-5]. Whilst elevated levels of endogenous oestrogens cannot justify alone the 64 correlation between obesity and endometrial cancer, experimental studies have shown that

65 adipokines, associated with hyperinsulinemia and insulin resistance, and inflammatory cytokines, associated to increased adiposity, may be also involved in the development of endometrial cancer [6].

Adiponectin, leptin, tumour necrosis factor alpha (TNF $\alpha)$, interleukin 6 (IL-6), insulin-like growth factor I and II (IGF-I and IGF-II), collectively termed adipocytokines, are hormones and cytokines secreted from adipocytes, and potentially key circulating molecules associated to endometrial cancer risk [7, 8].

Adiponectin, the most abundant circulating adipocytokines, plays an important role in regulating insulin and glucose metabolism, by promoting insulin secretion from pancreatic $\beta$ cells and facilitating insulin up-take in the liver [9-12]. Moreover, adiponectin has anti proliferative properties and, by activating AMP activated protein kinase (AMPK), inhibits cell growth, angiogenesis and promotes apoptosis in malignant cells [13]. Because of its properties and the fact that adiponectin is decreased in obesity, insulin resistance and type 2 diabetes, all 
independent risk's factors for endometrial cancer, circulating adiponectin levels may be an important factor in endometrial cancer.

80 Leptin affects the activity of several cell types and its main function involves regulating energy

81 intake and expenditure [14]. It has a role in glucose metabolism, as well as in the immune

82 system. Leptin is also secreted by cancer cells and its levels have been reported to be increased

83 in endometrial cancer and hyperplasia compared to controls with normal endometrium [15].

84 TNF $\alpha$ and IL-6 are pro-inflammatory cytokines released by macrophages within adipose tissue

85 and have been implicated in tumourigenesis. TNF $\alpha$ promotes cellular proliferation and prevents apoptosis by activating NFkB, [16], whereas IL-6 initiates tumour development and progression

87 through several pathways [17]. Both cytokines have been reported to be increased in 88 endometrial cancer and their pro-inflammatory actions play a role in cancer growth and metastasis by inducing reactive oxygen species and subsequent DNA damage and DNA repair inhibition [18]. IL-6 was found to be overexpressed in the stroma of endometrial cancer cells and TNF $\alpha$ was associated with poor survival $[19,20]$. However, other studies have not reported such an increase and found no difference in the expression of IL-6 in endometrial cancer and at

93 the various clinical stages [21].

94 IGF-I and IGF-II are growth factors involved in growth and development [22]. They are expressed in the normal development of the endometrium and also stimulated by oestrogen in

96 the uterus [23]. Epidemiological, clinical and experimental data have identified IGF-I and II as 97 important players in endometrial cancers. IGFs are thought to play a role in the initiation of 98 endometrial cancer due to oestrogen increasing the synthesis and expression of IGF-I which 99 stimulates cell proliferation thereby initiating endometrial cancer [24]; whereas IGF-II 100 expression was increased in advanced endometrial cancer compared to early stage endometrial 101 cancer [25]. Relative few studies have assessed the correlations between endometrial cancer 102 risk and circulating levels of IGF axis components: however a large degree of variability 
103 between studies and results was reported probably reflecting the complexity of this hormonal 104 system and the involvement of additional (hormonal or other) factors that can either positively 105 or negatively impinge upon IGF axis components.

106 Although evidences from in vitro and ex-vivo studies for a causal role of adipocytokines in 107 endometrial cancer are available, results from epidemiological studies are inconsistent. A 108 number of meta-analyses [26-28] have previously summarised epidemiological studies 109 investigating the relationship between circulating adiponectin and leptin concentrations and

110 endometrial cancer risk, however, to date, no meta-analysis has been performed to assess the 111 relationship between circulating levels of the pro-inflammatory cytokines, TNF $\alpha$ and IL-6, or 112 growth factors, IGF-I and IGF-II, and the risk of endometrial cancer. This study further clarifies 113 the association between circulating levels of leptin and adiponectin, and endometrial cancer, 114 and aimed to systematically assess the relationship between cytokines (IL- 6 and TNF $\alpha$ ) and 115 growth factors (IGF-I and IGF-II) levels with endometrial cancer risk via a meta-analysis of 116 observational studies.

\section{2. Methods}

119 2.1. Literature search

120 Meta-analysis was performed and reported by adopting the Meta-analyses of Observational 121 Studies in Epidemiology (MOOSE) guidelines [29]. English-language manuscripts published 122 between January 2000 and August 2018 were searched from the databases: Cochrane, 123 CINAHL, Embase, Medline and Web of Science. The following string of words was used for 124 searches in all databases - cancer and endometrial and (obesity or BMI) and (adiponectin or 125 TNF* or IGF-I or IGF-II or IL-6 or leptin). 
128 Published studies were included if they met the following criteria: the study i) used an 129 epidemiologic study design (e.g. case-control, case-cohort, nested case-control and cohort 130 study); ii) provided information on circulating adiponectin, leptin, TNF $\alpha$, IL-6, IGF-I, IGF-II 131 concentrations as exposure of interest; iii) reported endometrial cancer as the outcome of 132 interest; and iv) reported usable risk estimates (e.g. odds ratio, risk ratio or relative risk with $13395 \%$ confidence intervals between circulating adipocytokines levels and endometrial cancer 134 risk). In addition, if more than one study was conducted in the same population, the most recent 135 report or the report with the most applicable estimates was selected for analysis.

136 Published studies were excluded by the following exclusion criteria: i) non epidemiological 137 studies, reviews without original data, ecological studies, editorials and case reports; ii) the 138 study reported the risk estimates that could not be summarized (i.e. reported the risk estimates 139 without 95\% CIs); and iii) the study reported exclusively on endometrial cancer mortality. All 140 study selection and exclusion procedures were carried out by two independent investigators 141 (PEE and GB). If there was discordance, a third independent reviewer, GAB would make the 142 final decision.

\subsection{Data Extraction}

145 The following key data were extracted from each included study: first author's name, 146 publication year, study country, study design, number, ages and BMI of cases/controls, assay 147 methods, risk estimates, and matched or adjusted factors including age, body mass index (BMI), 148 menopausal status, whether they have had diabetes mellitus (DM) or hypertension, hormone replacement therapy (HRT) usage, parity or whether they smoked. 
152 Review Manager software, Version 5.3, was used to perform the meta-analysis: inverse 153 variance, odds ratio and random effect were chosen as statistical method, effect measure and 154 analysis model, respectively. The risk estimates were analysed as an estimation of odds ratio 155 (OR) or relative risk (RR) for simplicity. People with the levels of exposure in the top tertile 156 were compared with those in the bottom tertile. If the highest tertile (T3) and the lowest tertile 157 (T1) were not available from the individual studies [30-37], a scaling method similar to Danesh et al. [38] and used by Gong et al. [26] was applied: a scaling factor of 2.18 divided by 2.54

159 times the $\log$ OR for comparison of the top and bottom quartiles, or a scaling factor of 2.18 160 times the $\log$ OR for 1 standard deviation difference in the baseline levels of adiponectin or 161 leptin. In addition, some of the studies $[6,39]$ used the highest category of adiponectin rather 162 than the lower category as comparison: an effective count method described by Hamling and 163 colleagues [40], was therefore used to transform the comparison to the lowest tertile (T1). To 164 assess the relationship between circulating adipocytokines and the risk of endometrial cancer, 165 the summary of odds ratio (SOR) with 95\% CI was estimated. This was performed using a 166 random effect model of analysis. Chi-Squared test was used to assess the variation across the 167 studies, which was included in the forest plots. Heterogeneity across the studies was analysed 168 using the $\mathrm{I}^{2}$ statistics [41] and results were defined as heterogenous for an $\mathrm{I}^{2}>50 \%$. All 169 statistical tests were two-sided. $\mathrm{p}<0.05$ were considered to be statistically significant.

170 Sensitivity analysis was performed to assess the influence of individual studies on the pooled 171 OR and 95\% CI by excluding each study in turn.

172 Heterogeneity of the study results were explored by using stratified analyses and subgroup 173 analyses. These analyses included design of the study, fasting status for the collection of the 174 blood samples and the type of assay method used. Subgroup analyses to identify potential 175 confounders included BMI, hypertension, diabetes and menopausal status. A variable was 
176 considered confounding if they were found to be significantly associated with endometrial 177 cancer $\mathrm{p}<0.05$ on the univariate analysis.

\section{Results}

\subsection{Search Results and publication characteristics}

181 The database searches identified 473 publications. A total of 427 studies were excluded on title and abstract review as they did not meet the inclusion criteria as shown in Figure 1. The remaining 46 studies were reviewed for further details and full text retrieved. Twenty-six studies were excluded for not containing OR values, risk ratio or relative risk with $95 \% \mathrm{CI}$. Therefore, a total of 20 articles were included in this meta-analysis, which corresponded to 18 studies involving 2921 endometrial carcinoma cases and 5302 controls. Fourteen articles reported circulating levels for adiponectin $[6,8,31,36,37,39,42-49]$, 7 for leptin $[8,30,36$, reported values for IGF-II. The characteristics of these studies, all published between 2002 and 2015, are presented in Table 1.

\subsection{Adiponectin and its relationship to endometrial cancer risk}

193 In this current meta-analysis, fourteen studies evaluated adiponectin and its relationship to 194 endometrial cancer [6, 8, 31, 36, 37, 39, 42-49]. Two thousand and twenty-four endometrial 195 cancer cases and 3,593 controls were assessed in 9 retrospective studies ( 8 case control studies $196[6,31,36,37,42-45]$ and 1 cross sectional-controlled study [39]) and 5 prospective studies 197 (nested case control studies) [8, 46-49] (Table 1). Combined data showed a significant 198 difference between the risks of developing endometrial cancer in women with the highest 199 adiponectin levels compared to the lowest levels. Women with adiponectin concentrations in 200 the highest tertile had a reduced risk ( $\sim 0.5$ times) of endometrial cancer compared to women 

$\mathrm{p}<0.00001$ ). There was significant heterogeneity, $\mathrm{I}^{2}=77 \% \mathrm{p}<0.00001$ (Figure 2 ).

203 Sensitivity analysis was performed to determine whether any particular study had a greater 204 degree of influence between the association of adiponectin's levels and the risk of endometrial 205 cancer. Omitting each study one at a time and analysing the SOR of the rest of the studies, the 206 SOR ranged from 0.48 (95\% CI: 0.35-0.66, $\left.\mathrm{I}^{2}=79 \%, \mathrm{p}<0.00001\right)$ when omitting Soliman et al., 207 (2011) [46] study to 0.58 (95\% CI: 0.45-0.75, $\left.\mathrm{I}^{2}=67 \% \mathrm{p}=0.0002\right)$ when omitting Soliman et al., (2006) [6]. No single study had a larger influence over the other studies when assessing the association between adiponectin and endometrial cancer risk.

210 Stratifying by study design revealed a SOR of $0.64(95 \%$ CI: $0.41-0.99, p=0.05)$ for prospective studies [8, 46-49] and a SOR of $0.45(95 \%$ CI: $0.29-0.68, \mathrm{p}=0.0001)$ for the retrospective studies (Table 2) $[6,31,36,37,39,42-45]$. The heterogeneity was lower for the prospective studies $(56 \%, \mathrm{p}=0.06)$ compared to the retrospective studies $(83 \%, \mathrm{p}<0.00001)$. There were variations in the type of blood samples used as well as the method used to measure the concentration of 215 adiponectin. Eight studies [8, 31, 36, 37, 39, 43, 44, 47] used fasting samples to measure 216 adiponectin and in the other six [6, 42, 45, 46, 48, 49], it was not clear whether the blood 217 samples were fasted or postprandial. The point estimate for studies using fasting samples was 0.51 (95\% CI: $0.34-0.76, p=0.0009)$ and for the non-fasting studies, it was 0.51 (95\% CI: $0.32-$ $2190.81, \mathrm{p}=0.004)$. Eleven studies used an ELISA to measure adiponectin concentrations $[6,8,36$, $22037,39,42,43,44,46,47,49]$ and 3 studies used RIA/IMRA [31, 45, 48]. The point estimate 221 of SOR in the studies using the ELISA method was similar to the studies using RIA/IMRA 222 (SOR 0.53 vs 0.45$)$. Within prospective studies, there was no significant heterogeneity $\left(\mathrm{I}^{2}=56 \%\right.$ $223 \mathrm{p}=0.06)$, whereas there was within retrospective studies $\left(\mathrm{I}^{2}=83 \% \mathrm{p}<0.00001\right)$. Within studies 224 using fasting or non-fasting blood samples, there was significant heterogeneity $(\mathrm{p}=0.04$ and $225 \mathrm{p}<0.00001$, respectively). The studies using ELISA demonstrated statistically significant 
226 heterogeneity $(79 \% \mathrm{p}<0.00001)$ whereas the one using RIA/IMRA did not $(p=0.45)$. However

227 there was no evidence of significant heterogeneity between subgroups detected by meta228 regression analyses (Table 2).

229 Raised BMI, hypertension, diabetes and menopause are all risk factors for endometrial cancer.

230 Sub-analyses were performed to assess for potential confounding factors. When considering 231 BMI [6, 8, 31, 37, 39, 42-46, 49], the association between adiponectin levels and endometrial cancer risk is maintained (SOR 0.46, 95\% CI: 0.31-0.69, $\mathrm{p}=0.0002, \mathrm{I}^{2}=81 \%, \mathrm{p}<0.00001$ ). When considering hypertension [6, 36, 37, 42, 44, 47], diabetes [6, 37, 42, 44, 46-48], or menopause status $[8,31,36,37,39,42,44,47,48]$, a statistically significant association with endometrial cancers was maintained in the groups with hypertension (SOR 0.57, 95\% CI: $0.36-0.91, p=0.02$, $\mathrm{I}^{2}=81 \% \mathrm{p}<0.0001$ ), diabetes (SOR 0.6, 95\% CI: 0.38-0.94, $\mathrm{p}=0.03, \mathrm{I}^{2}=79 \% \mathrm{p}<0.001$ ) and post menopause (SOR 0.56, 95\% CI: $\left.0.40-0.80, \mathrm{p}=0.001, \mathrm{I}^{2}=70 \% \mathrm{p}=0.0007\right)$. This association was not lost in those without these conditions (Table 2).

\subsection{Leptin and its relationship to endometrial cancer risk}

241 A total of seven studies [8, 30, 36, 43, 44, 47, 48]; four retrospective $[30,36,43,44]$ and three prospective $[8,47,48]$, assessed the association between circulating leptin concentrations and

243 the risk of endometrial cancer. Three studies were nested case controls [8, 47, 48], and four 244 were case control studies [30, 36, 43, 44]. One thousand, one hundred and ninety-nine 245 endometrial cancers cases and 2076 control participants were assessed in the seven studies. The 246 forest plot of the combined data (Figure 3) demonstrated a summary of OR of 2.19 (95\% CI: 247 1.45-3.30, $\mathrm{p}=0.0002$ ). These results suggest a significant difference between the risk of 248 developing endometrial cancer in individuals with the highest leptin levels versus the lowest 249 levels. Women with leptin concentrations in the highest tertile had 2.19 times increased risk of 
endometrial cancer compared to women with leptin concentrations in the lowest tertile. There was variation between the studies, with significant heterogeneity, $I^{2}=64 \%, p=0.01$.

Sensitivity analysis was performed to determine whether any particular study had a greater degree of influence between the association of leptin and the risk of endometrial cancer. Omitting one study at a time and analysing the SOR of the rest of the studies, the SOR ranged from 1.99 (95\% CI: 1.37-2.91 p=0.0003, $\left.\mathrm{I}^{2}=58 \%, \mathrm{p}=0.03\right)$ when omitting Wu et al., (2014) [8] to 2.50 (95\% CI: $\left.1.84-3.40 \mathrm{p}<0.00001, \mathrm{I}^{2}=13 \% \mathrm{p}=0.330\right)$ when omitting Friedenreich et al., (2012) [36]. No single study had a larger influence over the other studies when assessing the association between leptin and endometrial cancer risk.

When stratifying by study design (Table 2), the prospective studies $[8,47,48]$ had a higher SOR of $3.32\left(95 \%\right.$ CI: $\left.1.98-5.56 \mathrm{p}<0.00001, \mathrm{I}^{2}=15 \%, \mathrm{p}=0.31\right)$ compared to the retrospective studies' SOR of 1.67 (95\% CI: 1.09-2.57 $\left.\mathrm{p}=0.02, \mathrm{I}^{2}=56 \%, \mathrm{p}=0.08\right)$ [30, 36, 43, 44]. There were variations between the type of samples used and the measurement of leptin concentration; 6 studies used fasting blood samples $[8,30,36,43,44,47]$ and 1 used a post prandial sample [48]. When comparing the type of samples, the point estimate of SOR for studies using non fasting blood samples was higher than the SOR for studies using fasting blood samples $(2.77$ vs 2.10). The concentration of leptin was either measured using an ELISA [8, 36, 43, 47] or RIA [44, 48], in 4 and 2 studies, respectively. In a further study, leptin was measured using an IMRA [30]. The point estimate of SOR for studies using ELISA was 2.27 (95\% CI: 1.16-4.42 $\left.\mathrm{p}=0.02, \mathrm{I}^{2}=75 \%, \mathrm{p}=0.007\right)$ and for the studies using RIA/IMRA was 2.45 (95\% CI: $1.67-3.59$ $\left.\mathrm{p}<0.00001, \mathrm{I}^{2}=0 \%, \mathrm{p}=0.45\right)$. Within prospective or retrospective studies there was no significant 271 heterogeneity $\left(\mathrm{I}^{2}=15 \% \mathrm{p}=0.31, \mathrm{I}^{2}=56 \% \mathrm{p}=0.08\right.$, respectively $)$, however there was evidence of significant heterogeneity $(\mathrm{p}=0.04)$ between subgroups detected by meta-regression analyses

273 (Table 2). Within studies using fasting blood samples [8, 30, 36, 43, 44, 47] and measuring 274 leptin levels by ELISA $[8,36,43,47]$, there was significant heterogeneity $\left(\mathrm{I}^{2}=65 \% \mathrm{p}=0.01\right.$ and 
$275 \mathrm{I}^{2}=75 \% \mathrm{p}=0.007$, respectively), whereas the one using non-fasting blood samples and 276 RIA/IMRA did not $(\mathrm{n} / \mathrm{a}$ and $\mathrm{p}=0.45)$. There was no evidence of significant heterogeneity

277 between the two subgroups detected by meta-regression analyses (Table 2).

278 Both pre and post-menopausal women were included in these studies. Other factors that were 279 matched/adjusted included BMI $(n=4)[8,30,43,44]$, hypertension $(n=3)[36,44,47]$, a history 280 of diabetes $(n=3)[44,47,48]$ and post-menopausal status $(n=5)[8,30,44,47,48]$. When BMI 281 is not considered [36, 47, 48], the overall association between leptin levels and the risk of 282 developing endometrial cancer is reduced to borderline levels, $\mathrm{p}=0.05$ (SOR 2.05 , 95\% CI 0.99$\left.2834.25, \mathrm{I}^{2}=80 \% \mathrm{p}=0.007\right)$. When considering patients with hypertension $[36,44,47]$, the overall 284 association between leptin levels and the risk of endometrial cancer is borderline $(p=0.06$, SOR $1.99,95 \%$ CI $0.98-4.04)$ whereas the overall association is increased when considering patients with diabetes $[44,47,48],(\mathrm{p}<0.00001$, SOR 2.80, 95\% CI 1.93-4.05). When post-menopausal status is not considered [36, 43], the overall association between leptin levels and the risk of developing endometrial cancer is lost, $\mathrm{p}=0.18$ (SOR 1.49, 95\% CI: 0.83-2.70). There was significant heterogeneity $\left(\mathrm{I}^{2}=76 \%, \mathrm{p}=0.02\right)$ in those studies that recorded hypertension compared to those studies that did not $\left(\mathrm{I}^{2}=42 \%, \mathrm{p}=0.16\right)$. For those studies that did not adjust

291 for the presence of diabetes in its participants, the heterogeneity was higher $\left(\mathrm{I}^{2}=68 \%, \mathrm{p}=0.02\right)$ compared to those studies that consider diabetes as confounding factor $\left(I^{2}=0 \%, p=0.91\right)$.

293 Similarly, for those studies that did not adjust for post-menopausal status, the heterogeneity was 294 higher $\left(\mathrm{I}^{2}=73 \%, \mathrm{p}=0.05\right)$ compared to those studies that consider it as confounding factor $295\left(\mathrm{I}^{2}=16 \%, \mathrm{p}=0.31\right)$. No evidence of significant heterogeneity between BMI, hypertension, 296 diabetes and post-menopausal status subgroups was detected by meta-regression analyses 297 (Table 2). 
300 The paucity of studies analysing TNF $\alpha$, IL-6 and IGF-I and their association with the risk of 301 endometrial cancer is evident (Table 1) [33, 34, 35, 50, 51]. Two studies (one prospective [35] 302 and one retrospective [50]) assessed both TNF $\alpha$ and IL-6 in a single cohort and a further 2 303 studies (both prospective) assessed TNF- $\alpha$ [34] and IL-6 [33] only. There was only one study 304 (prospective) investigating the role of IGF-I [51] and the risk of endometrial cancer. The total 305 number of endometrial cancer and control cases for TNF- $\alpha$ was 940 and 1781 respectively, and for IL-6, it was 975 and 1837, respectively. The prospective study assessing IGF-I and its 307 correlation with endometrial cancer risk had 166 cases and 315 controls.

308 From the meta-analyses, there appeared to be no association between circulating levels of TNF $\alpha$ 309 or IL-6 and overall risk of developing endometrial cancer (SOR=1.27, 95\% CI: $0.88-1.83$ 310 $\mathrm{p}=0.20, \quad \mathrm{SOR}=1.20,95 \%$ CI: 0.89-1.63, $\mathrm{p}=0.23$, respectively) (Figures $4 \mathrm{~A}$ and B).

311 Heterogeneity was not present for either TNF $\alpha$ studies or IL- 6 studies $\left(\mathrm{I}^{2}=65 \% \mathrm{p}=0.06\right.$ for $312 \mathrm{TNF} \alpha$, and $\mathrm{I}^{2}=42 \% \mathrm{p}=0.18$ for IL-6).

313 Sensitivity analysis was performed to determine whether any single study had a greater degree 314 of influence between the association of TNF $\alpha$ and the risk of endometrial cancer. When Wang et al., (2011) [35] was excluded, the SOR was 1.22 (95\% CI: $0.77-1.93 \mathrm{p}=0.39, \mathrm{I}^{2}=78 \%$ $\mathrm{p}=0.030$ ); excluding the study performed by Freidenreich et al., (2013) [50], the SOR was 1.58

317 (95\% CI: $\left.1.13-2.22 \mathrm{p}=0.007, \mathrm{I}^{2}=0 \%, \mathrm{p}=0.92\right)$ and finally excluding the study performed by 318 Dossus et al., (2011) [34], the SOR was 1.10 (95\% CI: 0.77-1.56 p=0.59, $\mathrm{I}^{2}=36 \%, \mathrm{p}=0.21$ ).

319 There are differences between the 3 studies which could explain the change in SOR; the Wang 320 study [35] was a prospective study and the studies by Friedenreich et al., (2013) [50] and Dossus 321 et al., (2011) [34] were retrospective and prospective studies, respectively. The participants in 322 the Wang et al., (2011) [35] study were postmenopausal women who were not using any 
323 hormone treatments. Both pre- and post-menopausal women were included in the other 2

324 studies and some participants in these 2 studies were also noted to be using hormones.

325 Sensitivity analysis was also performed to determine whether any single study had a greater 326 degree of influence between the association of IL-6 and endometrial cancer risk. The SOR 327 ranged from 1.06 (95\% CI: 0.76-1.49 $\left.\mathrm{p}=0.72, \mathrm{I}^{2}=18 \%, \mathrm{p}=0.27\right)$, when omitting the Dossus et $328 a l,(2010)[33]$ to a SOR of $1.29\left(95 \%\right.$ CI: $0.97-1.70 \mathrm{p}=0.08, \mathrm{I}^{2}=37 \% \mathrm{p}=0.21$, when excluding 329 the Wang et al., (2011) [35] study. Excluding the Friedenreich et al., (2013) [50] study, the 330 SOR was 1.15 (95\% CI: 0.56-2.34 $\left.\mathrm{p}=0.71, \mathrm{I}^{2}=66 \%, \mathrm{p}=0.09\right)$.

331 Only one prospective study [51] investigated the association of pre-diagnostic blood 332 concentrations of IGF-I and other factors associated to hyperinsulinemia with endometrial 333 cancer risk. While increased circulating C-peptide levels were associated with increased 334 endometrial cancer risk, the risk was unrelated to IGF-I levels (OR 0.90, 95\% CI 0.44-1.82, p $335=0.54$ ) when case-control pairs were matched for study cohort, age at recruitment into the study, 336 menopausal status, and adjusted for BMI and HRT use.

\section{Discussion}

339 Inflammation, an important factor in the development and progression of cancer, has been 340 implicated in the link between obesity and cancer [52, 53]. Adiponectin, leptin, TNF- $\alpha$, IL-6 341 and IGF-I are biological factors that are involved in different stages of the inflammatory 342 pathway. To the best of our knowledge, this study is the most updated meta-analysis examining 343 the relationship between circulating levels of adiponectin and leptin, and endometrial cancer; 344 and the first one to assess the association between TNF $\alpha$, IL-6, IGF-I and IGF-II and 345 endometrial cancer risk. Our findings indicated that decreased circulating levels of adiponectin 346 and increased levels of leptin are associated with increased endometrial cancer risk, whereas no 
347 difference in cancer risk were observed between participants with the highest TNF $\alpha$ and IL-6

348 levels.

349 The paucity of studies reported in the literature investigating the link between the 350 adipocytokines and endometrial cancer is evident; between 2000 and 2018, only 20 publications

351 were found in the literature that met the inclusion criteria set. Undertaking a systematic review 352 and meta-analysis increased population size enhancing the accuracy and precision of the 353 findings from the various studies and allowing a greater understanding of the association 354 between adipocytokines and endometrial cancer risk. Our analyses concurred with other 355 reported studies $[43,48]$ on the association between adiponectin and leptin concentration levels 356 and endometrial cancer risk: increased adiponectin serum levels and decreased leptin levels are 357 associated with an overall decreased risk of endometrial cancer. It was found that women with 358 higher levels of adiponectin had the risk of developing endometrial cancer decreased by half 359 compared to those women with lower levels of adiponectin. Women with high levels of leptin 360 had a two-fold increased risk of developing endometrial cancer compared to women with low 361 levels of leptin. Similarly to the findings in this meta-analysis, low serum adiponectin levels 362 and high serum leptin levels have been associated to increased risk of other types of cancer (e.g. 363 colon and breast cancer) $[54,55]$. In colorectal cancer patients, the association between TNF $\alpha$, 364 adiponectin and leptin has also been assessed concluding that leptin levels correlated with TNF $\alpha$ 365 levels and that TNFa levels were an independent predictor of increased leptin levels [54]. Such 366 association may be present in endometrial cancer, and leptin and TNF $\alpha$ may act synergistically 367 to promote the development of endometrial cancer due to evidence that leptin promotes low 368 grade inflammation by elevating levels of TNF $\alpha[56]$.

369 The studies reported by Dallal et al., (2013) [47] and Soliman et al., (2011) [46] did not find an 370 association between adiponectin serum levels and endometrial cancer risk, possibly due to the 371 limited numbers of cases and controls Moreover, both studies were prospective, and slight 
372 differences between the prospective and retrospective studies were highlighted by the sub 373 analyses carried out (Table 2). For adiponectin, the SOR was 0.64 for prospective studies 374 compared to 0.45 for retrospective with statistical difference for retrospective studies $375(\mathrm{p}=0.0001)$ and for leptin, the SOR for prospective studies was $3.32(\mathrm{p}<0.00001)$ compared to $3761.67(\mathrm{p}=0.02)$ for retrospective studies.

377 There have been limited studies assessing TNF- $\alpha$ and IL-6 and its risk with endometrial cancer. 378 TNF- $\alpha$ and IL-6 play an important role in promoting carcinogenesis through the activation of 379 various transcription factors and multiple oncogenic pathways. However, no significant 380 associations between these two markers and risk of cancers were observed in the current meta381 analysis. Despite the limited number of studies, the number of endometrial cancer cases and 382 controls were relatively high; 940 vs 1781 and 975 vs 1837 cases vs controls, respectively. 383 When assessing the individual studies, Wang et al., 2011 [35] and Friedenreich et al., 2013 [50] 384 did not find an association between TNF $\alpha$ and IL-6 which is in contrast to the studies conducted 385 by Dossus et al., 2010, 2011 [33,34]. The risk of endometrial cancer appears not to be initiated 386 by TNF $\alpha$ and IL-6, but may develop through other inflammatory pathways, such as genetic 387 aberrations in PTEN or NFKB genes and the increased production of other mediators of 388 inflammation [57]. Similar results related to the association of increased risk of endometrial 389 cancer with TNF- $\alpha$ and IL-6 were also found in a recent systematic review and meta-analysis 390 on circulating adipokines and their risk to obesity related cancers including breast, colorectal, 391 kidney pancreatic, prostate, endometrial, and multiple myeloma cancers [58].

392 The only study considering the association of circulating levels of IGF-I with endometrial 393 cancer, showed no association, in agreement with a study by Petridou et al., [59] which showed 394 that endometrial cancer was positively associated with IGF-II and inversely with IGF-I. This 395 study adds to the gradually developing consensus that components of the IGF system play a 396 central role in human carcinogenesis, and that IGF-II, rather than IGF-I, may be closely linked 
to the aetiology of endometrial cancer, one of the types of cancer most strongly associated with obesity.

399 Different study populations have differing characteristics, including BMI levels and presence 400 of hypertension and diagnosis of diabetes. Further sub-analyses were performed to identify any 401 other factors that could affect the risk of endometrial cancer. Tables 2 summarises the OR of 402 the association between circulating adiponectin, leptin and endometrial cancer stratified by 403 study characteristics. BMI appeared to affect the association between circulating leptin levels 404 and endometrial cancer risk, but not with circulating adiponectin levels and endometrial cancer 405 risk. Hypertension and diabetes appear to affect the association between circulating leptin levels 406 but not between adiponectin levels and increased endometrial cancer risk. Adiponectin and 407 leptin may act synergistically and increase the risk of endometrial cancer. This is not the case 408 for TNF- $\alpha$ and IL-6.

409 The strength of our research is that this study presents a relatively comprehensive review of the 410 existing evidence on the association of various adipocytokines and endometrial cancer. In 411 particular, stratified analysis using a variety of selected variables has strengthened our results 412 against the influence of confounding. There were also limitations to the meta-analysis; the 413 number of cases in each study was relatively small, however the overall number of endometrial 414 cancer cases in the meta-analysis was high, 2921. Retrospective studies were included and 415 therefore, there is always a risk of potential bias in the form of recall bias.

416 This meta-analysis is the first to assess multiple adipocytokines in relation to endometrial 417 cancer risk. Larger prospective studies assessing a variety of adipocytokines in the same cohort 418 of patients are required to investigate further the association between adipocytokines and 419 endometrial cancer, especially studies considering circulating levels of TNF- $\alpha$, IL-6 and IGF I 420 and II. This would allow elucidating in more details, the exact mechanisms underlying the link 421 between adipocytokines and endometrial cancer. 


\section{Ethics approval and consent to participate}

424 In this meta-analysis, we used only previously published data. Because no unpublished data

425 were used, we did not seek ethics committee approval. The study is in accordance with the 426 tenets of the Declaration of Helsinki.

427

428

Consent for publication

429 Not applicable.

430

431

Data availability

432 Not applicable.

433

434 Authors' contributions

435 PEE, GAB, and GB conceptualized this study, developed the protocol, and wrote the

436 manuscript. PEE and GB selected articles for full-text review, extracted data from the included

437 studies, and performed all statistical analyses.

438

439 Declaration of competing interest

440 None.

442 Acknowledgements

443 This work was supported by the Centre for Obesity Research and Education, Robert Gordon 444 University, Aberdeen

445

References 
[1] Cancer Research UK, 2018. https://www.cancerresearchuk.org.

[2] Endometrial Cancer Report, World Cancer Research Fund, 2013.

449 [3] Berstein LM, Tchernobrovkina AE, Gamajunova VB, Kovalevskij AJ, Vasilyev DA, 450 Chepik OF, et al. (2003). Tumor estrogen content and clinico-morphological and endocrine 451 features of endometrial cancer. J Cancer Res Clin Oncol. 129: 245-9.

452 [4] Slater M, Cooper M \& Murphy CR. (2006) Human growth hormone and interleukin-6 are 453 upregulated in endometriosis and endometrioid adenocarcinoma. Acta Histochemica,108, $13-18$.

455

[5] Choi D.S, Kim H.J, Yoon J.H, Yoo SC, Jo H, Lee SY et al. (2009). Endometrial cancer invasion depends on cancer -derived tumour necrosis factor- $\alpha$ and stromal derived hepatocyte growth factor. International Journal of Cancer.124, 2528-2538.

[6] Soliman PT, Wu D, Tortolero-Luna G, Schmeler K., Slomovitz B, Bray M, Gershenson D, Lu K. (2006) Association between Adiponectin, Insulin Resistance, and Endometrial Cancer, 106,2376-2381.

461 [7] Modugno F., Ness R.B, Chen C., Weiss N.S. (2005) Inflammation and endometrial cancer: a hypothesis. Cancer Epidemiology, biomarkers \& Prevention 14,2840-2847.

[8] Wu M, Chen H, Chen C, You S, Cheng W, Chen C (2014). A prospective study of gynecological cancer risk in relation to adiposity factors: cumulative incidence and association with plasma adipokine levels. PLOS ONE 9, 1-10.

466 [9] Berg AH, Combs TP, Du X, Brownlee M, Scherer PE. (2001) The adipocyte-secreted protein Acrp30 enhances hepatic insulin action. Nature Medicine, 7 ,941-6.

[10] Yamauchi T., Kamon J., Waki H., Terauchi Y., Kubota N., Hara K et. Al., (2001). The fatderived hormone adiponectin reverses insulin resistance associated with both lipoatrophy and obesity. Nature Medicine 7:941-946. 
471 [11] Kharroubi, I., Rasschaert, J., Eizirik, D.L., Cnop, M.L. (2003) Expression of adiponectin receptors in pancreatic $\beta$ cells, Biochemical and Biophysical Research. Communications. $312,1118-1122$.

474 [12] Lihn AS. Pedersen, SB. Richelsen, B. (2005). Adipoenctin: action, regulation and association to insulin sensitivity. Obesity review, 6,13-21.

[13] Barb D., C.J. Williams, Neuwirth C.S. (2007) Adiponectin in relation to malignancies: a review of existing basic research and clinical evidence. Am. J. Clinical Nutrition. 86,858S$866 \mathrm{~S}$

[14] Daley-Brown D., Oprea-LLies G., Lee R., Pattillo R. (2015) Molecular cues on obesity signals, tumor markers and endometrial cancer. Hormone Molecular Biological Clinical Investure ,21(1), 89-106.

[15] Cymbaluk A, Chudecka-Glaz, Izabella Rzepka- Gorska. (2008). Leptin levels in serum depending on body mass index in patients with endometrial hyperplasia and cancer. European Journal of Obstetrics \& Gynecology and Reproductive Biology, 136 ,74-77.

[16] Phillip M., Rowley D.A., Schreiber H., (2004). Inflammation as a tumour promoter in cancer induction. Seminars in Cancer Biology 14, (6), 433-9.

[17] Ara T, Declerck YA. (2010) Interleukin-6 in bone metastasis and cancer progression. European Journal Cancer, 46,1223-31.

489 [18] Bellone S, Watts K, Cane S, Palmieri M et al. (2005). High serum levels of IL-6 in endometrial carcinoma are associated with uterine serous papillary histology, a highly aggressive and chemotherapy resistant variant of endometrial cancer, Gynecological Oncology, 98,92-8.

[19] Smith H.O, Stephens, ND, Qualls C.R, Fligelman T., Wang, T, Lin C-Y , Burton E, Griffith J.K, Pollard J.W. (2013) The clinical significance of inflammatory cytokines in primary cell culture in endometrial carcinoma. Molecular Oncology, 7(1), 41-54. 
[20] Uzan J, Laas E, Alsamad I, Skalli D, Monsouri D, Haddad B, Touboul C. (2017). Supervised Clustering of Adipokines and Hormonal Receptors Predict Prognosis in a Population of Obese Women with Type 1 Endometrial Cancer. International Journal of Molecular Sciences, 18, 1055, 1-13.

500 [21] Chopra V., Dinh TV, Hannigan EV. Serum levels of interleukins, growth factors and 501 angiogenin in patients with endometrial cancer (1997). J cancer Research Clinical Oncology. 123,167-72.

503

[22] Agrogiannis CD, Sifakis S, Patsouris ES, Konstantinidou AE. (2014) Insulin-like growth factors in embryonic and fetal growth and skeletal development. Molecular Medicine Reports. 10,579-84.

[23] Murphy LJ,A Ghahary (1990) Uterine insulin -like growth factor I :regulation of 507 expression and its role in estrogen inducing uterine proliferation. Endocrine reviews. 11, 443-453.

[24] Majchrzak Baczmanska D, Malinowski A, (2006). Does IGF-1 play a role in the biology of endometrial cancer? Ginekologia Polska. 87(8): 598-604.

511 [25] Pavelic J, Radakovic B, Pavelic K. (2007). Insulin like growth factor 2 and its receptors (IGF-1R and IGF 2R/Mannose 6-phosphate) in endometrial adenocarcinoma. Gynecological Oncology,105 (3), 727-735.

514 [26] Gong T-T, Wu Q-J, Wang Y-L, Ma-X-X. (2015) Circulating adiponectin, leptin and 515 adiponectin-le ptin ratio and endometrial cancer risk: Evidence from a meta-analysis of 516 epidemiologic studies. International Journal of Cancer, 137, 19676-1978.

517 [27] Zeng F, Shi J, Long Y, Tian H, Li X, Zhao AZ, et al. (2015) Adiponectin and Endometrial 518 Cancer: A Systematic Review and Meta-Analysis. Cell Physiology Biochemistry, 36, (4) $1670-8$. 
520 [28] Lin T., Zhao X., Kong W-M (2017) Association between adiponectin levels and 521 endometrial carcinoma risk: evidence from a dose response meta-analysis. BMJ Open, 5, $522 \quad 1-7$

523 [29] Stroup D, Berlin J, Morton S, Olkin I, Williamson G, Rennie D, Moher D, Becker B, Sipe 524 T, Thacker S (2000) For the Meta-analysis Of Observational Studies in Epidemiology 525 (MOOSE) Group. Meta-analysis of Observational Studies in Epidemiology. A proposal for Reporting. JAMA 283, 2008-2012.

527 [30] Petridou E, Belerchri M, Dessypris N, Koukoulomatis P, Diakomanolis E, Spanos E, et al., (2002). Leptin and body mass index in relation to endometrial cancer risk. Annual Nutrition Metabolism, 46,147-51.

530 [31] Petridou E, Mantzoros C, Dessypris N, Koukoulomatis P, Addy C, Voulgaris Z (2003). Plasma adiponectin concentration in relation to endometrial cancer: a case-control study in Greece. The Journal of Clinical Endocrinology \& Mechanism 88, 993-997.

533 [32] Cust A, Kaaks R, Friedenreich, Bonnet F, Laville M, Lukanova A, et al. (2007) Plasma Adiponectin levels and endometrial cancer risk in pre- and postmenopausal women. The Journal of Clinical Endocrinology \& Metabolism 92, 255-263.

[33] Dossus L, Rinaldi S, Becker S, Lukanova A, Tjonneland A, Olsen A, et al. (2010). Obesity, inflammatory markers and endometrial cancer risk: a prospective case-control study. Endocrine-Related Cancer 17, 1007-1019.

539 [34] Dossus L, Rinaldi S, Becker S, Lukanova A, Tjonneland A, Olsen A, et al. (2011). Tumour necrosis factor (TNF)- $\alpha$, soluble TNF receptors and endometrial cancer risk: the EPIC study. International Journal of Cancer ,129, 2031-2037.

542 [35] Wang T, Rohan TE, Gunter MJ, Xue X, Wactawski-Wende J, Rajpathak SN, et al. (2011). 543 A prospective study of inflammation markers and endometrial cancer risk in 544 postmenopausal hormone nonusers. Cancer Epidemiol Biomarkers Prev. 20: 971-7. 
545 [36] Friedenreich C, Langley A, Speidel T, Lau D, Courneya K, Csizmadi I, et al. (2012). Case546 control study of markers of insulin resistance and endometrial cancer risk. Endocrine$547 \quad$ Related Cancer (2012) 19 785-792.

548 [37] Ohbuchi Y, Suzuki Y, Hatakeyama I, Nakao Y, Fujito A, Iwasaka T (2014). A lower serum 549 level of middle- molecular -weight adiponectin is a risk factor for endometrial cancer, $550 \quad$ International Journal of Clinical Oncology, 19, 667-673.

551 [38] Danesh J,Collins R, Appleby P et al. (1998) Association of fibrinogen, c-reactive protein,albumin or leukocyte count with coronary heart disease: meta analyses of prospective studies. Jam Med Assoc 279 1477-82.

554 [39] Erodogan S, Sezer S, Baser E, Gun-Eylimaz O, Gungor E, Uysal S, (2013) Evaluating vaspin and adiponectin in postmenopausal women with endometrial cancer. EndocrineRelated Cancer 20, 669-675.

557 [40] Hamling J, Lee P, Weitkunat R. Ambuhl M (2008). Facilitating meta-analyses by deriving relative effect and precisions estimates for alternative comparisons from a set of estimates presented by exposure level or disease category. Stat Med: 27:954-70.

560 [41] Higgins J, Thompson S (2002). Quantifying heterogeneity in a meta-analysis. Statistics in medicine 21(11) 1539-1558.

562 [42] Zhang L, Wen K, Han X, Liu R, Qu Q. (2015) Adiponectin mediates antiproliferative and apoptotic responses in endometrial carcinoma by the AdipoRs/AMPK pathway. Gynecol Oncol. 137: 311-20.

[43] Ma Y, Zhiwei L, Zhang Y, Bingjian L, (2013). Serum leptin, adiponectin and endometrial cancer risk in chinese women. Journal of Gynecologic Oncology 24,336-341.

567 [44] Ashizawa N, Yahata T, Quan J, Adachi S, Yoshihara K, Tanaka K. (2010). Serum Leptin568 adiponectin ratio and endometrial cancer risk in postmeopausal female subjects. $569 \quad$ Gynecologic Oncology 119: 65-69 
[45] Dal Maso L, Augustin LS, Karalis A, Talamini R, Franceschi S, Trichopoulos D, et al., (2004). Circulating adiponectin and endometrial cancer risk. J Clin Endocrinol Metab. 89: 1160-3.

[46] Soliman PT, Cui X, Zhang Q, Hankinson S, Lu K. (2011). Circulating adiponectin levels and risk of endometrial cancer: the prospective nurses' health study. American Journal of Obstetrics \& Gynecology 204, e1-5.

[47] Dallal C, Brinton L, Brauer D, Buist D, Cauley J, Hue T, et al. (2013). Obesity-related hormones and endometrial cancer among postmenopusal women: a nested case-control study within B FIT cohort. Endocrine-Related Cancer 20, 151-160.

[48] Luhn P, Dallal C, Weiss J, Black A, Huang W, Lacey, Jr J. (2013). Circulating adipokine levels and endometrial cancer risk in the prostate, lung, colorectal, and ovarian cancer screening trial. Cancer, Epidemiology, Biomarkers \& Prevention, 22, 1304-1312.

[49] Cust AE, Kaaks R, Friedenreich C, Bonnet F, Laville M, Lukanova A, Rinaldi S, et al. (2007). Plasma adiponectin levels and endometrial cancer risk in pre- and postmenopausal women. J Clin Endocrinol Metab. 92: 255-63.

[50] Friedenreich C, Langley A, Speidel T, Lau D, Courneya K, Csizmadi I, et al. (2013). Casecontrol study of inflammatory markers and the risk of endometrial cancer. European Journal of cancer Prevention ,13, 374-379.

[51] Lukanova A, Zeleniuch-Jacquotte A, Lundin E, Micheli A, Arslan AA, Rinaldi S, et al., (2004) Prediagnostic levels of C-peptide, IGF-1, IGFBP-1, -2 and -3 and risk of endometrial cancer. Int. J. cancer 108: 262-268.

[52] Arendt LM, McCready, Keller P, Kelle P, Baker D, Naber S, Seewalt V. Obesity promotes breast cancer by CCL2- mediated macrophage recruitment and angiogenesis. Cancer Res 73 (2013) 6080-6093. 
594 [53] Bowers L, Brenner A, Hursting S, Rajeshwar T, deGraffenried L Obesity -associated systemic interleukin-6 promotes pre-adipocyte aromatase expression via an increased breast cancer cell prostaglandin E2 production. Breast Cancer Res Treat 149 (2015), 4957.

598 [54] Guadagni F, Roselli M, Martini F, Spila A., Riondino S, D’Alessandro R, et al., (2009) 599 Prognostic significance of serum adipokine levels in colorectal cancer patients. Anticancer 600 Res 29:3321-7.

601 [55] Tworoger SS, Eliassen AH, Kelesidis T, Colditz GA, Willett WC, Mantzoros CS et al. (2007) Plasma concentrations and the risk of incident breast cancer. J Clin Endocrinol Metab. 92: 1510-6.

604 [56] Strong Al., Burrow ME, Gimble JM, Bunnell BA, (2015) Concise review: The obesity 605 cancer paradigm: exploration of the interactions and crosstalk with adipose stem cells. Stem Cells, 33, 318-326.

607 [57] Wallace AE, Douglas GA, Saunders PTK, Jabbour HN. (2010) Inflammatory events in endometrial adenocarcinoma. Journal of Endocrinology , 206,141-157.

609 [58] Yoon YS, Kwon AR, Lee YK, Oh SW. (2019). Circulating adipokines and risk of obesity related cancers: A systematic review and meta-analysis. Obesity Research \& Clinical $611 \quad$ Practice 13: 329-339.

612 [59] Petridou E, Koukoulomatis P, Alexe DM, Voulgaris Z, Spanos E, Trichopoulos D. (2003) 613 Endometrial cancer and the IGF system: a case-control study in Greece. Oncology, 64: $341-510$. 
617 Characteristics of included articles $(n=20)$

\begin{tabular}{|c|c|c|c|c|c|c|c|}
\hline $\begin{array}{l}\text { First author, } \\
\text { Year, } \\
\text { Study Country }\end{array}$ & $\begin{array}{l}\text { Study } \\
\text { design }\end{array}$ & $\begin{array}{l}\text { No. of } \\
\text { case/control }\end{array}$ & $\begin{array}{l}\text { Age of } \\
\text { case/control }\end{array}$ & $\begin{array}{l}\text { BMI of } \\
\text { case/control }\end{array}$ & $\begin{array}{l}\text { Biomarkers } \\
\text { (assay method) }\end{array}$ & $\begin{array}{l}\text { Risk Estimates } \\
(95 \% \text { CI }) \\
\text { Exposure } \\
\text { categories }\end{array}$ & Adjusted factors \\
\hline \multicolumn{8}{|c|}{ Retrospective studies } \\
\hline $\begin{array}{l}\text { Zhang, } \\
2015 \\
\text { China }\end{array}$ & $\begin{array}{l}\text { Case } \\
\text { control }\end{array}$ & $88 / 90$ & $\begin{array}{l}64.7 \pm 10.1 \mathrm{a} \\
58.7 \pm 8.6 \mathrm{~b}\end{array}$ & $\mathrm{n} / \mathrm{a}$ & $\begin{array}{l}\text { Adiponectin } \\
\text { (ELISA) }\end{array}$ & $\begin{array}{l}\text { OR } 0.822 \\
(0.759-0.889) \\
\text { Not specified in text }\end{array}$ & Age, BMI, WHR, diabetes, hypertension \\
\hline $\begin{array}{l}\text { Ohbuchi, } \\
2014 \\
\text { Japan }\end{array}$ & $\begin{array}{l}\text { Case } \\
\text { control }\end{array}$ & $43 / 62$ & $\begin{array}{l}61.2 \pm 9.8 \mathrm{a} \\
58.1 \pm 8.3 \mathrm{~b}\end{array}$ & $\begin{array}{l}26.1 \pm 4.5 a \\
23.3 \pm 3.8 b\end{array}$ & $\begin{array}{l}\text { Adiponectin } \\
\text { (ELISA) }\end{array}$ & $\begin{array}{l}\text { OR } 1.987 \\
(0.290-13.617) \\
\text { Q1 vs Q2 }\end{array}$ & Age, BMI, diabetes, hypertension \\
\hline $\begin{array}{l}\text { Erodogan, } \\
2013 \\
\text { Turkey }\end{array}$ & $\begin{array}{l}\text { Cross } \\
\text { sectional } \\
\text { controlled } \\
\text { study }\end{array}$ & $60 / 70$ & $\begin{array}{l}56.57 \pm 9.05 a \\
49.7 \pm 7.59 b\end{array}$ & $\begin{array}{l}31.12 \pm 4.18 \mathrm{a} \\
27.49 \pm 3.22 \mathrm{~b}\end{array}$ & $\begin{array}{l}\text { Adiponectin } \\
\text { (ELISA) }\end{array}$ & $\begin{array}{l}\text { OR } 10.64 \\
(3.61-31.40) \\
\text { T1 vs T3 }\end{array}$ & Age, BMI, HOMA-IR, QUICKI \\
\hline $\begin{array}{l}\text { Friedenreich, } \\
2013 \\
\text { Canada }\end{array}$ & $\begin{array}{l}\text { Case } \\
\text { control }\end{array}$ & $519 / 964$ & $\begin{array}{l}58.7 \\
58.3\end{array}$ & $\begin{array}{l}32.3 \\
28.1\end{array}$ & $\begin{array}{l}\text { TNF- } \alpha \\
\text { (ELISA) } \\
\text { IL-6 } \\
\text { (ELISA) }\end{array}$ & $\begin{array}{l}\text { OR } 1.00 \\
(0.84-1.18) \\
\text { OR } 1.15 \\
(0.89-1.48) \\
\text { Not specified in text }\end{array}$ & $\begin{array}{l}\text { Age, BMI, nulliparity, physical activity, } \\
\text { hypertension, alcohol consumption, } \\
\text { hormone usage }\end{array}$ \\
\hline $\begin{array}{l}\text { Ma, } \\
2013 \\
\text { China }\end{array}$ & $\begin{array}{l}\text { Case } \\
\text { control }\end{array}$ & $206 / 310$ & $\begin{array}{l}53.2(26-81) b \\
53.3(27-82) b\end{array}$ & $\mathrm{n} / \mathrm{a}$ & $\begin{array}{l}\text { Adiponectin } \\
\text { (ELISA) } \\
\text { Leptin } \\
\text { (ELISA) }\end{array}$ & $\begin{array}{l}\text { OR } 0.52 \\
(0.32-0.83) \\
\text { OR } 2.05 \\
(1.28-3.29) \\
\text { T3 vs T1 } \\
\end{array}$ & $\begin{array}{l}\text { Age, BMI, glucose, cholesterol, } \\
\text { triglycerides, HDL cholesterol, insulin, } \\
\text { adiponectin (for leptin), leptin (for } \\
\text { adiponectin) }\end{array}$ \\
\hline
\end{tabular}




\begin{tabular}{|c|c|c|c|c|c|c|c|}
\hline $\begin{array}{l}\text { Friedenreich, } \\
2012 \\
\text { Canada }\end{array}$ & $\begin{array}{l}\text { Case } \\
\text { control }\end{array}$ & $514 / 961$ & $\begin{array}{l}59(53,65) \mathrm{c} \\
59(52,66) \mathrm{c}\end{array}$ & $\begin{array}{l}31.0(26.4,36.8) \mathrm{c} \\
27.2(24.1,30.9) \mathrm{c}\end{array}$ & $\begin{array}{l}\text { Adiponectin } \\
\text { (ELISA) } \\
\text { Leptin } \\
\text { (ELISA) }\end{array}$ & $\begin{array}{l}\text { OR } 0.55 \\
(0.37-0.80) \\
\text { OR } 1.14 \\
(0.73-1.77) \\
\text { Q4 vs Q1 }\end{array}$ & $\begin{array}{l}\text { Age, weight, waist to hip ratio, nulliparity, } \\
\text { HRT, hypertension, glucose, insulin, } \\
\text { adiponectin (for leptin), leptin (for } \\
\text { adiponectin) }\end{array}$ \\
\hline $\begin{array}{l}\text { Ashizawa, } \\
2010 \\
\text { Japan }\end{array}$ & $\begin{array}{l}\text { Case } \\
\text { control }\end{array}$ & $146 / 150$ & $\begin{array}{l}59.9 \pm 8.9 \mathrm{a} \\
57.5 \pm 7.4 \mathrm{a}\end{array}$ & $\begin{array}{l}23.7 \pm 4.5 \mathrm{a} \\
22 \pm 3.3 \mathrm{a}\end{array}$ & $\begin{array}{l}\text { Adiponectin } \\
\text { (ELISA) } \\
\text { Leptin } \\
\text { (RIA) }\end{array}$ & $\begin{array}{l}\text { OR } 0.6 \\
(0.3-1.2) \\
\text { OR } 2.6 \\
(1.4-4.9) \\
\text { T3 vs T1 }\end{array}$ & Age, BMI, hypertension, diabetes \\
\hline $\begin{array}{l}\text { Soliman, } \\
2006 \\
\text { USA }\end{array}$ & $\begin{array}{l}\text { Case } \\
\text { control }\end{array}$ & $117 / 238$ & $\begin{array}{l}66.6(25-88) b \\
61.2(50-80) b\end{array}$ & $\begin{array}{l}33.2 \\
28.0\end{array}$ & $\begin{array}{l}\text { Adiponectin } \\
\text { (ELISA) }\end{array}$ & $\begin{array}{l}\text { OR } 10.5 \\
(4.18-26.35) \\
\text { T1 vs T3 }\end{array}$ & Age, BMI, diabetes, hypertension, \\
\hline $\begin{array}{l}\text { Dal Maso, } \\
2004 \\
\text { Italy }\end{array}$ & $\begin{array}{l}\text { Case } \\
\text { control }\end{array}$ & $87 / 132$ & $\begin{array}{l}62(34-78) d \\
61(29-72) d\end{array}$ & $\begin{array}{l}27.8(25.4-32) \mathrm{e} \\
25.1(22.3-27.9) \mathrm{e}\end{array}$ & $\begin{array}{l}\text { Adiponectin } \\
\text { (RIA) }\end{array}$ & $\begin{array}{l}0.30 \\
(0.14-0.68) \\
\text { T3 vs T1 }\end{array}$ & $\begin{array}{l}\text { Age, BMI, parity, education, HRT use, } \\
\text { smoking status }\end{array}$ \\
\hline $\begin{array}{l}\text { Petridou, } \\
2003 \\
\text { Greece }\end{array}$ & $\begin{array}{l}\text { Case } \\
\text { control }\end{array}$ & $84 / 84$ & $\mathrm{n} / \mathrm{a}$ & $\mathrm{n} / \mathrm{a}$ & $\begin{array}{l}\text { Adiponectin } \\
\text { (RIA) }\end{array}$ & $\begin{array}{l}\text { OR } 0.78 \\
(0.56-1.10) \\
1 \text { SD increment }\end{array}$ & $\begin{array}{l}\text { Age, BMI, height, education, age at } \\
\text { menarche, pregnancy, IGF-I, IGF-II, } \\
\text { IGFBP-3 and leptin }\end{array}$ \\
\hline $\begin{array}{l}\text { Petridou, } \\
2002 \\
\text { Greece }\end{array}$ & $\begin{array}{l}\text { Case } \\
\text { control }\end{array}$ & $84 / 84$ & $\begin{array}{l}63.3 \pm 9.69 \mathrm{a} \\
62.6 \pm 11.3 \mathrm{a}\end{array}$ & $\begin{array}{l}29.2 \pm 5.72 \mathrm{a} \\
26.5 \pm 3.43 \mathrm{a}\end{array}$ & $\begin{array}{l}\text { Leptin } \\
\text { (IRMA) }\end{array}$ & $\begin{array}{l}\text { OR } 1.13 \\
(0.70-1.81) \\
\text { 1SD increment }\end{array}$ & $\begin{array}{l}\text { Age, education, height, age at menarche, } \\
\text { menopausal status, history of pregnancy } \\
\text { by outcome, alcohol and coffee } \\
\text { consumption, smoking status }\end{array}$ \\
\hline \multicolumn{8}{|c|}{ Prospective studies } \\
\hline $\begin{array}{l}\text { Wu, } \\
2014 \\
\text { Taiwan }\end{array}$ & $\begin{array}{l}\text { Nested } \\
\text { case } \\
\text { control }\end{array}$ & $20 / 120$ & $\begin{array}{l}44.3 \pm 8.5 \mathrm{a} \\
46.6 \pm 9.8 \mathrm{a}\end{array}$ & $\mathrm{n} / \mathrm{a}$ & $\begin{array}{l}\text { Adiponectin } \\
\text { (ELISA) } \\
\text { Leptin } \\
\text { (ELISA) }\end{array}$ & $\begin{array}{l}\text { OR } 0.07 \\
(0.01-0.62) \\
\text { OR } 10.68 \\
(2.09-54.67) \\
\text { T3 vs T1 } \\
\end{array}$ & Age, BMI, years of estrogen exposure \\
\hline $\begin{array}{l}\text { Soliman, } \\
2011 \\
\text { USA }\end{array}$ & $\begin{array}{l}\text { Nested } \\
\text { case } \\
\text { control }\end{array}$ & $146 / 377$ & $\begin{array}{l}57(47-67) b \\
57(47-67) b\end{array}$ & $\begin{array}{l}27.2 \\
25.5\end{array}$ & $\begin{array}{l}\text { Adiponectin } \\
\text { (ELISA) }\end{array}$ & $\begin{array}{l}\text { OR } 0.98 \\
(0.57-1.68) \\
\text { T3vs T1 }\end{array}$ & Age, BMI, parity, diabetes \\
\hline $\begin{array}{l}\text { Dallal, } \\
2013 \\
\text { USA }\end{array}$ & $\begin{array}{l}\text { Nested } \\
\text { case } \\
\text { control } \\
\text { study }\end{array}$ & $62 / 124$ & $\begin{array}{l}67.4 \pm 5.5 \mathrm{a} \\
67.5 \pm 5.1 \mathrm{a}\end{array}$ & $\begin{array}{l}29.5 \pm 6.9 \mathrm{a} \\
26.8 \pm 4.7 \mathrm{a}\end{array}$ & $\begin{array}{l}\text { Adiponectin } \\
\text { (ELISA) } \\
\text { Leptin } \\
\text { (ELISA) }\end{array}$ & $\begin{array}{l}\text { OR } 0.87 \\
(0.39-1.94) \\
\text { OR } 3.29 \\
(1.41-7.69) \\
\text { T3 vs T1 } \\
\end{array}$ & $\begin{array}{l}\text { Age, estradiol, C-peptide and BMI, } \\
\text { diabetes }\end{array}$ \\
\hline
\end{tabular}




\begin{tabular}{|c|c|c|c|c|c|c|c|}
\hline $\begin{array}{l}\text { Luhn, } \\
2013 \\
\text { USA }\end{array}$ & $\begin{array}{l}\text { Nested } \\
\text { case } \\
\text { control }\end{array}$ & $167 / 327$ & $\begin{array}{l}66.4 \pm 5.7 \mathrm{a} \\
\mathrm{n} / \mathrm{a}\end{array}$ & $\mathrm{n} / \mathrm{a}$ & $\begin{array}{l}\text { Adiponectin } \\
\text { (RIA) } \\
\text { Leptin } \\
\text { (RIA) }\end{array}$ & $\begin{array}{l}\text { OR } 0.48 \\
(0.29-0.80) \\
\text { OR } 2.77 \\
(1.60-4.79) \\
\text { T3 vs T1 }\end{array}$ & $\begin{array}{l}\text { Age, HRT, current smoking status, family } \\
\text { history of breast and endometrial cancer, } \\
\text { education, parity, diabetes, oral } \\
\text { contraception use }\end{array}$ \\
\hline $\begin{array}{l}\text { Dossus, } \\
2011 \\
\text { Europe }\end{array}$ & $\begin{array}{l}\text { Nested } \\
\text { case } \\
\text { control }\end{array}$ & $270 / 518$ & $\begin{array}{l}57.0(6.9) \mathrm{a} \\
57.0(6.9) \mathrm{a}\end{array}$ & $\begin{array}{l}28.1(5.9) \mathrm{a} \\
26.3(4.5) \mathrm{a}\end{array}$ & $\begin{array}{l}\text { TNF } \alpha \\
\text { (ELISA) }\end{array}$ & $\begin{array}{l}\text { OR } 1.73 \\
(1.09-2.73) \\
\text { Q4 vs Q1 }\end{array}$ & $\begin{array}{l}\text { Age, BMI, nulliparity, age at menopause, } \\
\text { HRT use }\end{array}$ \\
\hline $\begin{array}{l}\text { Wang, } \\
2011 \\
\text { USA }\end{array}$ & $\begin{array}{l}\text { Case } \\
\text { cohort }\end{array}$ & $151 / 299$ & $\begin{array}{l}65.2(7.1) \mathrm{a} \\
63.5(7.5) \mathrm{a}\end{array}$ & $\begin{array}{l}29.7(7.8) \mathrm{a} \\
27.5(5.8) \mathrm{a}\end{array}$ & $\begin{array}{l}\text { IL-6 } \\
\text { (ELISA) } \\
\text { TNF } \alpha \\
\text { (multiplex } \\
\text { assay) }\end{array}$ & $\begin{array}{l}\text { OR } 0.70 \\
(0.29-1.68) \\
\text { OR } 1.65 \\
(0.77-3.54) \\
\text { Q4 vs Q1 }\end{array}$ & Age, BMI, Free IGF-I, estradiol, insulin \\
\hline $\begin{array}{l}\text { Dossus, } \\
2010 \\
\text { Europe }\end{array}$ & $\begin{array}{l}\text { Nested } \\
\text { case } \\
\text { control }\end{array}$ & $305 / 574$ & $\begin{array}{l}56.9(7.3) \mathrm{a} \\
57.1(7.4) \mathrm{a}\end{array}$ & $\begin{array}{l}27.5(5.5) \mathrm{a} \\
26.0(4.3) \mathrm{a}\end{array}$ & $\begin{array}{l}\text { IL-6 } \\
\text { (ELISA) }\end{array}$ & $\begin{array}{l}\text { OR 1.66 } \\
(1.08-2.54) \\
\text { Q4 vs Q1 }\end{array}$ & BMI, C-peptide, estrone \\
\hline $\begin{array}{l}\text { Cust, } \\
2007 \\
\text { Europe }\end{array}$ & $\begin{array}{l}\text { Nested } \\
\text { case } \\
\text { control }\end{array}$ & $284 / 548$ & $\begin{array}{l}56.9(45.4- \\
67.9) \mathrm{f} \\
56.9(45.0- \\
68.0) \mathrm{f}\end{array}$ & $\begin{array}{l}28.1(20.9- \\
37.60) \mathrm{f} \\
26.5(20.2-34.8) \mathrm{f}\end{array}$ & $\begin{array}{l}\text { Adiponectin } \\
\text { (ELISA) }\end{array}$ & $\begin{array}{l}\text { OR } 0.63 \\
(0.36-1.10) \\
\text { Q4 vs Q1 }\end{array}$ & $\begin{array}{l}\text { Age, BMI, C-peptide, IGFBP-1, IGFBP-2, } \\
\text { SHBG, estrone, free testosterone }\end{array}$ \\
\hline $\begin{array}{l}\text { Lukanova, } \\
2004 \\
\text { USA, Sweden, } \\
\text { Italy }\end{array}$ & $\begin{array}{l}\text { Case } \\
\text { control }\end{array}$ & $166 / 315$ & $\begin{array}{l}61 \pm 7.8 \mathrm{a} \\
\mathrm{n} / \mathrm{a}\end{array}$ & $\begin{array}{l}27.3(26.5-28.0) \mathrm{g} \\
25.3(24.7-25.9) \mathrm{g}\end{array}$ & $\begin{array}{l}\text { IGF-1 } \\
\text { (RIA) }\end{array}$ & $\begin{array}{l}\text { OR } 0.90 \\
(0.44-1.82) \\
\text { Q5 vs Q1 }\end{array}$ & $\begin{array}{l}\text { Age, menopausal status, day of menstrual } \\
\text { cycle for pre-menopausal women }\end{array}$ \\
\hline
\end{tabular}

BMI, body mass index; WHR, waist-to-hip-ratio; ELISA ,enzyme linked immunosorbent assay; HOMA-IR, homeostasis model assessment of insulin

resistance; QUICKI, quantitative insulin sensitivity check index; IGF, insulin like growth factor; IGFBP, insulin like growth factor binding protein; SHBG,

sex hormone binding globulin; HRT, hormone replacement therapy; OR , odds ratio; RIA, radio-immuno assay.

a: mean $\pm S D$; b: mean (range); c: median $\left(25^{\text {th }}, 75^{\text {th }}\right.$ percentile); d: median (range); e: median (interquartile range); f: mean $\left(5^{\text {th }}-95^{\text {th }}\right.$ percentiles $)$; g: mean $(95 \%$

confidence interval); n/a: not available 
625 Summary of OR of the relationship between adiponectin or leptin and possible risk factors for endometrial cancer

\begin{tabular}{|c|c|c|c|c|c|c|c|c|c|c|c|c|}
\hline \multicolumn{7}{|c|}{ Adiponectin } & \multicolumn{6}{|c|}{ Leptin } \\
\hline \multicolumn{2}{|l|}{ No of study } & SOR & $95 \%$ CI & $\mathbf{I}^{2}$ & ${ }^{1} p$ value & ${ }^{2} p$ value & $\begin{array}{l}\text { No of } \\
\text { study }\end{array}$ & SOR & $95 \%$ CI & $\mathbf{I}^{2}$ & ${ }^{1} p$ value & ${ }^{2} p$ value \\
\hline \multicolumn{13}{|l|}{ Study design } \\
\hline Prospective & 5 & 0.64 & $0.41-0.99$ & $56 \%$ & $p=0.06$ & \multirow[t]{2}{*}{$p=0.27$} & 3 & 3.32 & $1.98-5.56$ & $15 \%$ & $p=0.31$ & \multirow[t]{2}{*}{$p=0.04$} \\
\hline Retrospective & 9 & 0.45 & $0.29-0.68$ & $83 \%$ & $P<0.00001$ & & 4 & 1.67 & $1.09-2.57$ & $56 \%$ & $p=0.08$ & \\
\hline \multicolumn{13}{|c|}{ Fasting blood samples } \\
\hline Yes & 8 & 0.51 & $0.34-0.76$ & $52 \%$ & $p=0.04$ & \multirow[t]{2}{*}{$p=1$} & 6 & 2.10 & $1.31-3.38$ & $65 \%$ & $p=0.01$ & \multirow[t]{2}{*}{$\mathrm{n} / \mathrm{a}$} \\
\hline No & 6 & 0.51 & $0.32-0.81$ & $85 \%$ & $p<0.00001$ & & 1 & 2.77 & $1.60-4.80$ & $\mathrm{n} / \mathrm{a}$ & $\mathrm{n} / \mathrm{a}$ & \\
\hline \multicolumn{13}{|l|}{ Assay method } \\
\hline ELISA & 11 & 0.53 & $0.38-0.75$ & $79 \%$ & $\mathrm{p}<0.00001$ & \multirow[t]{2}{*}{$p=0.52$} & 4 & 2.27 & $1.16-4.42$ & $75 \%$ & $p=0.007$ & \multirow[t]{2}{*}{$p=0.85$} \\
\hline RIA/IMRA & 3 & 0.45 & $0.31-0.65$ & $0 \%$ & $p=0.45$ & & 3 & 2.45 & $1.67-3.59$ & $0 \%$ & $p=0.45$ & \\
\hline \multicolumn{13}{|l|}{ BMI } \\
\hline Yes & 11 & 0.46 & $0.31-0.69$ & $81 \%$ & $P<0.00001$ & \multirow[t]{2}{*}{$p=0.31$} & 4 & 2.35 & $1.43-3.88$ & $39 \%$ & $p=0.18$ & \multirow[t]{2}{*}{$p=0.76$} \\
\hline No & 3 & 0.59 & $0.45-0.76$ & $0 \%$ & $p=0.46$ & & 3 & 2.05 & $0.99-4.25$ & $80 \%$ & $p=0.007$ & \\
\hline \multicolumn{13}{|l|}{ Hypertension } \\
\hline Yes & 6 & 0.57 & $0.36-0.91$ & $81 \%$ & $P<0.0001$ & \multirow[t]{2}{*}{$p=0.54$} & 3 & 1.99 & $0.98-4.04$ & $76 \%$ & $p=0.02$ & \multirow[t]{2}{*}{$p=0.66$} \\
\hline No & 8 & 0.47 & $0.31-0.70$ & $64 \%$ & $p=0.007$ & & 4 & 2.42 & $1.47-3.97$ & $42 \%$ & $p=0.16$ & \\
\hline \multicolumn{13}{|l|}{ Diabetes } \\
\hline Yes & 7 & 0.6 & $0.38-0.94$ & $79 \%$ & $\mathrm{P}<0.001$ & \multirow[t]{2}{*}{$p=0.31$} & 3 & 2.80 & $1.93-4.05$ & $0 \%$ & $p=0.91$ & \multirow[t]{2}{*}{$p=0.23$} \\
\hline No & 7 & 0.44 & $0.30-0.65$ & $60 \%$ & $P=0.02$ & & 4 & 1.80 & $0.97-3.35$ & $68 \%$ & $p=0.02$ & \\
\hline
\end{tabular}


Menopausal status

\begin{tabular}{|l|l|l|l|}
9 & 0.56 & $0.40-0.80$ \\
\hline 5 & 0.44 & $0.25-0.81$
\end{tabular}

$70 \%$

$70 \%$

$p=0.0007$ $p=0.47$

\begin{tabular}{|l|l|l|l|l|l|}
\hline 5 & 2.75 & $1.87-4.05$ & $16 \%$ & $\mathrm{P}=0.31$ & $\mathrm{P}=0.09$ \\
\hline 2 & 1.49 & $0.83-2.70$ & $73 \%$ & $\mathrm{P}=0.05$ & \\
\hline
\end{tabular}

${ }^{1} \mathrm{p}$ value for heterogeneity within each subgroup; ${ }^{2} \mathrm{p}$ values for heterogeneity between subgroups with meta-regression analysis 


\section{Figure legends}

628 Figure 1: Flow diagram of screened, excluded and analysed publications

629 Figure 2: Forest plots representing the association between circulating levels of adiponectin 630 and the risk of endometrial cancer risk. The red squares represent the OR of the individual

631 studies and the horizontal lines through the boxes represent the $95 \%$ coefficient interval. The 632 overall treatment effect is represented by the black diamond.

633 Figure 3: Forest plots representing the association between circulating levels of leptin and the

634 risk of endometrial cancer risk. Red squares represent the OR of the individual studies and the 635 horizontal lines through the boxes represent the $95 \%$ coefficient interval. The overall treatment 636 effect is represented by the black diamond.

637 Figure 4: Forest plots representing the association between circulating levels of TNF $\alpha$ (A) or 638 IL-6 (B) and the risk of endometrial cancer risk. The red squares represent the OR of the 639 individual studies and the horizontal lines through the boxes represent the $95 \%$ coefficient 640 interval. The overall treatment effect is represented by the black diamond. 
Total publications identified on first screening of databases using the string of words: Cancer and endometrial and (obesity or BMI) and (adiponectin or $\mathrm{TNF}^{*}$ or IGF-I or IGF-II or IL-6 or leptin) $n=473$

CINAHL $n=5$; Cochrane $n=6$; Embase $n=149 ;$ Medline $n=92$; Web of Science $n=221$

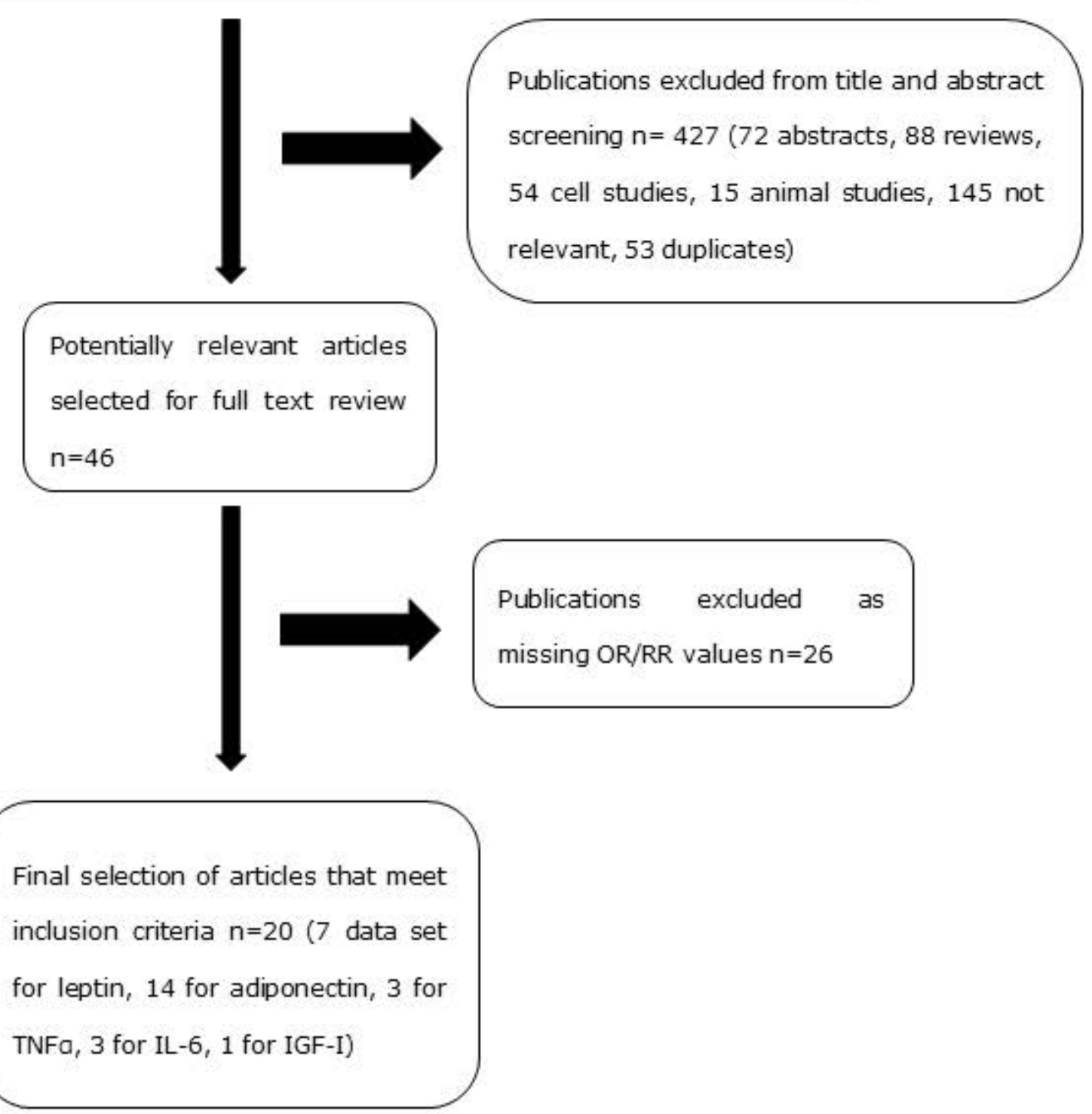




\section{Odds Ratio Odds Ratio}

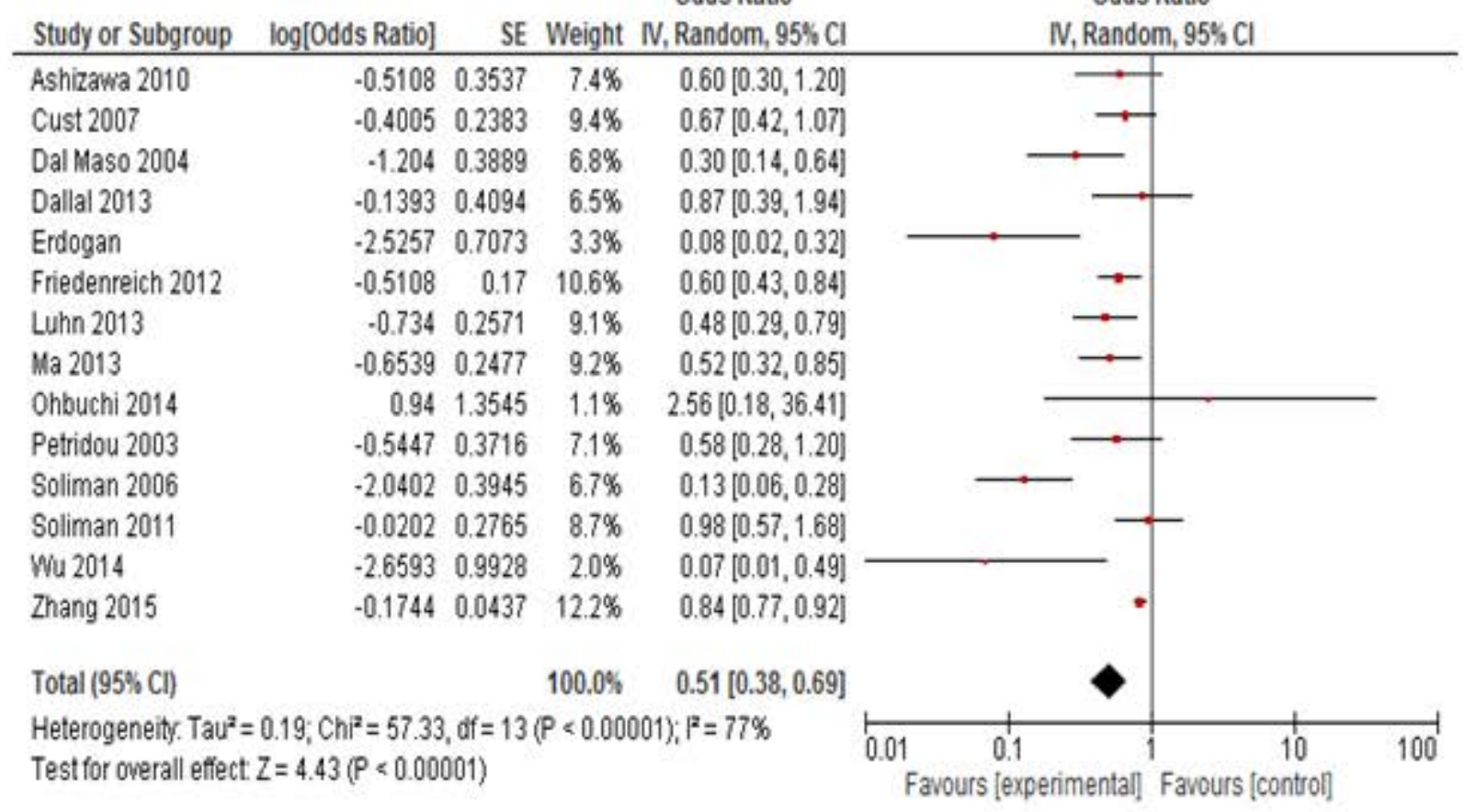


Odds Ratio

Odds Ratio

Study or Subgroup log[Odds Ratio] SE Weight IV, Random, $95 \% \mathrm{Cl}$ $\mathrm{N}$, Random, $95 \% \mathrm{Cl}$

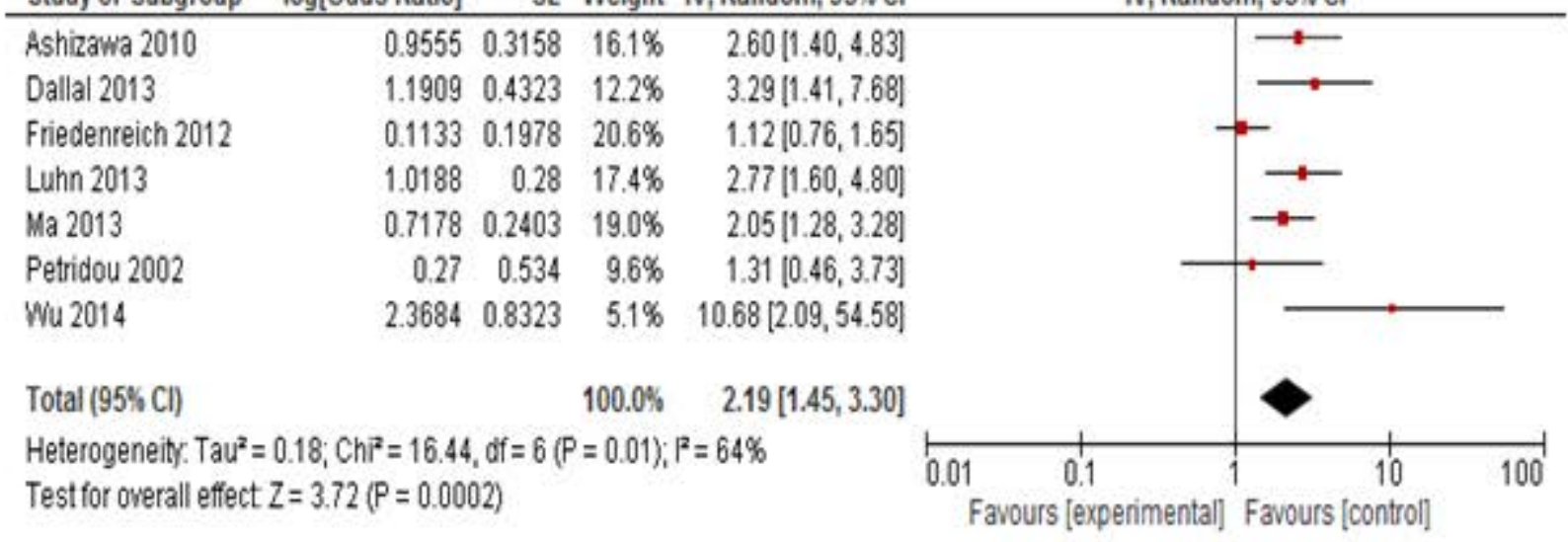




\section{A)}

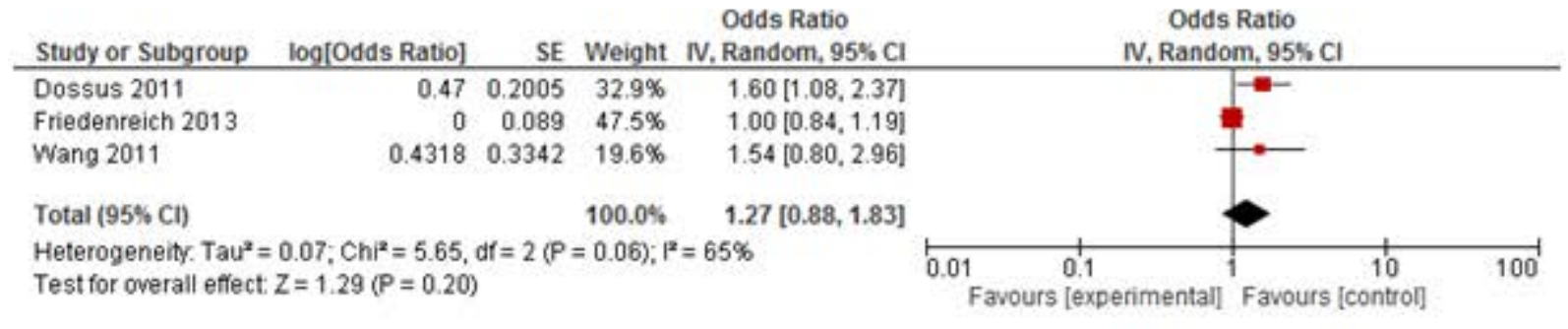

B)

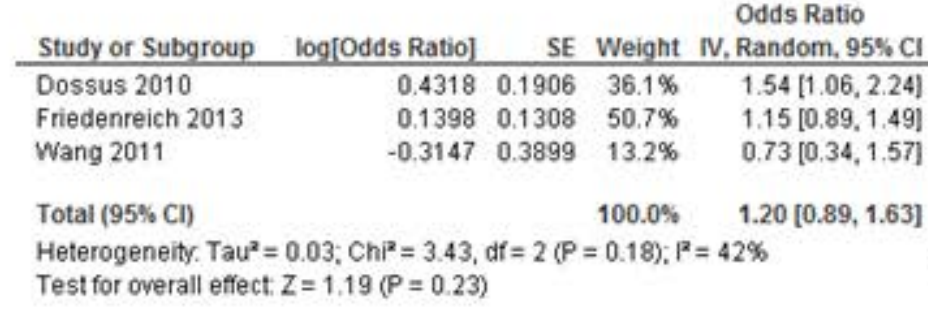

Odds Ratio

Odds Ratio

Test for overall effect: $Z=1.19(P=0.23)$

IV, Random, $95 \% \mathrm{Cl}$ 